Biljana Dojčinović

University of Belgrade

bdojcinovic@fill.bg.ac.rs

ORCID: 0000-0002-8684-2350

Ana Kolarić

University of Belgrade

ana.kolaric@fil.bg.ac.rs

ORCID: 0000-0001-8300-539X
Data przesłania tekstu do redakcji: 30.06.2020

Data przyjęcia tekstu do druku: 02.09.2020

\title{
Towards a Different Knowledge: the Knjiženstvo Database and the Digitisation of Materials*
}

\begin{abstract}
Dojčinović Biljana, Kolarić Ana, Towards a Different Knowledge: the Knjiženstvo Database and the Digitisation of Materials. "Poznańskie Studia Slawistyczne" 19. Poznań 2020. Publishing House of the Poznan Society for the Advancement of the Arts and Sciences, Adam Mickiewicz University, pp. 41-60. ISSN 2084-3011.

The first part of this paper introduces the concept of digital humanities and the phases that some researchers note in the development of the humanities in new, digital media, as well as the role of digital humanities in the promotion of the marginalised literatures, particularly that written by women. The core example is the digital database Knjiženstvo, certain segments of which contain not only the data on the texts, but the digitised texts as well. In this paper, we pose the question on how databases can be involved in the creation of new knowledge at all educational levels. To this effect, we necessarily expand certain segments of the database to include those publications on which they already contain information. In relation to this, it has been observed that one of the greatest problems is the part of the database dealing with the periodicals - both women and feminist - and therefore, the second part of the paper is dedicated to this topic. We first analyze the terms women and feminist magazines, and afterwards, we consider the ways in which the materials from these periodicals could be gathered, classified and connected.
\end{abstract}

KEYwORDS: digital database; education; digitisation; periodicals

* This is an updated version of the text Биљана Дојчиновић and Ана Коларић (2017). Research reported in this paper was done within the framework of project Knjiženstvo: Theory and History of Women's Writing in Serbian until 1915, financed by the Ministry of Education, Science and Technological Development of the Republic of Serbia. 
Although we have been surrounded by the digital world for several decades, readily using its advantages, digital media is examined differently when it comes to the educational and academic sphere. A study about the digitisation processes published in 2017 (Mitrović, 2017) shows that Serbia started the adoption of the information and communication technologies (ICT) relatively late, but it was only after 2005 that the interest in this matter started to grow. Over the course of this period, the infrastructure was also improved and thus preconditions were fulfilled for a more rapid development of the information society (Mitrović, 2017, 6), but certain persisting obstacles still exist: expensive Internet, "insufficient participation of the highly educated population and a low level of electronic content on the Internet in Serbian" (Mitrović, 2017, 7).

In other words, the engagement of the educational and academic community in digitisation process would obviously stimulate better development of this sector. The same text, however, states that only 47 percent of teachers hold that the level of information and communication technologies equipment in schools is satisfactory, and that more than half of them are lacking access to digital cabinets or, if they do not, those cabinets are used less than once a month (Mitrović, 2017, 7). Additionally, we find that "albeit the business sector in Serbia is relatively well equipped with ICT, these capacities are very badly exploited precisely because of the lack of interdisciplinary knowledge and skills of the employees" (Mitrović, 2017, 7).

The conclusion of the study is a sort of warning against the conservative approach in the academic sphere:

Reform programs towards greater interdisciplinarity of studies, which should facilitate the transition to information society, can be seriously compromised by the traditional rigidity existing within the university, where it takes a lot of time to implement genuine changes. This, in addition to the very little interest of the adult population in lifelong learning, represents one of the most serious threats to the development and digitisation of Serbia (Mitrović, 2017, 9).

In support of this claim, the fact is that in the academic sphere the term "digital humanities" continues to cause suspicion raising often the question - what is this about ${ }^{1}$ ? Not letting digital humanities become some sort

${ }^{1}$ The advantages of the digital humanities seem to become only clear recently when the online teaching became the only way to maintain regular activities during Covid-19 pandemic. 
of a bogeyman, its basic activities are to be explicated as well as its possible opportunities for a lifelong and interdisciplinary education, that is, ways of producing knowledge in a new and interesting way (for more on the interdisciplinary and transdisciplinary character of digital humanities, v. Dojčinović, 2016, 76-77). The simplest answer to the aforementioned question is that this notion implies a combination of humanistic disciplines accompanied by computer technologies. Basic activities in digital humanities are: collecting data, data curation, analysis, editing and modeling. Furthermore, new media have the possibility of video and audio recordings and their distribution, combination, montage (Burdick et al., 2012, 11). Therefore, a new emphasis on oral art is placed on, and even more so on the visual aspect - video recordings, data visualization, the very design in which the text is (which is no longer just text) "packaged" (Burdick et al., 2012, 11-13).

In case of the Knjiženstvo database, which was established in 2011, having a relatively small number of visual materials, there are almost no audio materials, and even digitised texts are not its primary content. This database, modeled on the database of European women authors Women's Writers in History, ${ }^{3}$ is conceived as a cyber space where basic bio-bibliographical data about women authors who started writing in Serbian by 1915 are to be obtained.

However, the constant development of the digital sphere has led to the appearance of a large number of texts on the Internet related to individual authors from the database and which are simply linked to the entry. In this way, we get more than a list of references, but less than a digital database of whole texts. As a platform for researchers, this kind of a database is more than sufficient - it is open to changes, updates and new discoveries which are expected in the case of subjects that were previously underdeveloped. The question that inevitably follows is - how can such digital database be useful to education and at what level?

In an attempt to answer this question, we are starting with the idea which is at the core of the project Knjiženstvo - introducing women writers, such as Jelena Dimitrijević, Milica Janković, Milica Stojadinović Srpkinja

\footnotetext{
${ }^{2}$ For the description and objectives of the project and database in particular, v. www. knjizenstvo.rs.

${ }^{3}$ Its updated version is at http://resources.huygens.knaw.nl/womenwriters/vre.
} 
and others, into the curriculum, that is, into the canon of Serbian literature; or, if they already find themselves there, encouraging better understanding of their literary and social role.

The canon itself is one of the most inflexible indicators of the conservative nature of academia. As Magdalena Koch notes, "the canon, to most, remains a firm synonym of the forced, symbolic 'exile' from the main streams of culture, which condemns to non-reading, that is, to the factual inexistence of texts in the wide cultural space" (Kox, 2017, 3). How to change that? Digital humanities are ideal for the affirmation of the marginalised. The virtual space is open for the introduction of new findings and, on condition that it involves open access, which is the only solution that makes sense, information becomes available to everyone that owns a computer, tablet or a phone with an internet connection. Information, of course, still does not constitute knowledge, but databases should be organised in such a manner so that the data in them become knowledge. They can form alternative canons, or, rather, anti-canons, because, instead of the hierarchical order found in traditional literary histories, there are network, three-dimensional connections here.

In this particular case, with the support of the digital database Knjiženstvo, which has existed for ten years, introducing women writers in the teaching canon would include direct connections with available research. This process would include training pupils and students in using electronic resources and creating data for digital databases, which contributes to fulfilling goals we have already mentioned at the beginning of the text. On the other hand, the question is, at what level of education should the intervention into the canon, that is, into the required reading that emanates the canon, start? And can this database help at that point?

The draft of the project Knjiženstveni Beograd (GynoCentric Belgrade) received support from the Faculty of Philology and the Institute for Literature and Art to participate in the call of the Centre for the Promotion of Science; however, unfortunately, it did not receive the funds from the Centre. ${ }^{4}$ This project demonstrates those possibilities in an interesting manner. It

\footnotetext{
${ }^{4}$ The draft of the project was made by Jelena Milinković from the Institut za književnost i umetnost (Institute for Literature and Arts), Željka Janković from the Faculty of Philology and the project Knjiženstvo, and Biljana Dojčinović, with significant help from Ljubica Ćorović from the Local History Department of the Belgrade City Library.
} 
includes walking tours through the centre of Belgrade with stops at places that are connected with certain authors present in the Knjiženstvo database. The proposed implementation of the project encompassed initially the creation of an interactive map Knjiženstveni centar Beograda, which would show the locations in the centre of Belgrade related to selected authors and linked to the corresponding page in Serbian and English in the database of the Knjiženstvo project. Another segment would include the actual walks through the city centre which would be led by members of the team for a limited amount of time, in Serbian, English or French. When constructing the draft, we took into consideration that this includes a relatively small area in the very centre of the city and that the duration of the walk should not exceed two hours. Of course, that is not sufficient time to actually learn something about the authors we are talking about, but, since each of these authors has an entry in the digital database Knjiženstvo, which can be accessed via the interactive map $^{5}$ or directly on the Knjiženstvo website, that means that true learning about these authors starts through the digital database on women authors, before or after the actual walk. Further numerous activities could be developed from this project, both tourist and research, because it includes connecting the real and the cyber space. It is easy to imagine that walks could be done with various groups: e.g. with children from preschools and elementary schools, adapted to their interests and tasks within their curriculum; exiting classrooms would, at the same time, represent the entry into the real space perceived differently precisely due to the data from the virtual space. Different variants would be intended for residents or visitors of Belgrade of all ages and levels of education, while in the virtual space, practically anyone could create their own walk with the information provided by the Knjiženstvo database. In other words, the draft of this project shows that the digital space is becoming a narrative space - the walk through the digital and/or real space is simultaneously a story about possibilities of different choices; therefore, a story more about de-canonisation than a new or alternative canon.

Ideally, such a stroll would take us directly to the texts of the aforementioned female writers. Let us take Jelena Dimitrijević for example; in the real

${ }^{5}$ https://www.google.com/maps/d/viewer?mid=1 xdIQP60-03MJbAm7KTBGY7n-JDA\&1l=44.8149329028337\%2C20.458130849999968\&z=16. 1.09.2020. 
space of 'Knjiženstveni' Belgrade she would occupy the spot in Francuska St. 29 - the address where she lived for more than four decades. Her house, still in its place, lies there unmarked, similarly to many other places from this suppressed map of the city. For our hypothetical stroller to create a virtual map of her movements across the globe, in a quite literal sense - from Kruševac where she was born, across Belgrade, Vienna, New York, Cairo, Damascus, Kolkata and many other places she visited - one would have to inform themselves about the author. The Knjiženstvo database contains more information about Jelena Dimitrijević than about any other author - the total of 170 female writers so far. What is more, she is the author with the largest number of digitalised texts - be they of primary or secondary kind. In the digital journal Knjiženstvo alone from 2011 to 2020, there have been ten or so texts published on her, ranging from academic papers to reviews of her republications in addition a number of existing texts from different periods and sources. As for Jelena Dimitrijević's texts, the city library of Kruševac had some of them scanned on their website, under the column Native authors. Those included several short stories as well as Letters from Niš (regarding Harems), Letters from Thessaloniki, Letters from India, along with the first part of the travelogue Seven Seas and Three Oceans. Seeing that Jelena Dimitrijević's work have started being reprinted and republished (Dimitrijević, 2003, 141-191; 2008; 2012; 2016a, 140-193; 2016b; 2017; 2019), online sources - convenient as they may be - are not necessarily the best versions, as new publications often come with forewords and prologues containing important discoveries. For this reason, it is advisable to use reprints rather than online sources. Jelena Dimitrijević's manuscripts, kept in the National Library of Serbia, are available to researchers. Scanning these manuscripts is subject to a fee and posting them online is not permitted. In October 2020, the Knjiženstvo project's work on the second part of the previously unpublished travelogue Seven Seas and Three Oceans was completed, and the manuscript published. Meanwhile, a book of her stories and poems from American cycle has been published (Дојчиновић, 2019), as well as the bilingual book of her poems in French, translated to Serbian (Dimitriyévitch, 2020). Also, in 2019, Jelena J. Dimitrijević's travelogue Seven Seas and Three Oceans (part I) became a compulsory reading for seventh grade of primary schools, which means that this writer has finally become part of a school canon. 
The question remains - what would be the real challenge in the instance of digitising Jelena Dimitrijević's texts? The answer is - the material which was published in periodicals. Considering that Jelena Dimitrijević regularly published in the Serbian Literary Herald and other literary journals, as well as in the Politika daily and particularly in the Circle of Serbian Sister's journal Vardar, periodicals could be an incredibly interesting and important source for establishing context and reconstructing works of this and other authors. The Knjiženstvo database contains a section on periodical publications but it has not been developed as much as other elements of the database as it requires additional data labelling. The European database, which served as a model for the Knjiženstvo one, does not contain a section on periodicals, as it would further complicate the overview of European women's literature. In part, this is understandable if we take into consideration the scope of the European circle but in a database limited to a certain language it has become too difficult to form a comprehensive insight into the context in which the $19^{\text {th }}$-century work was read without having access to the journal culture of the time. In this way, our hypothetical stroll through the database would end at the place where journals, newspaper and other periodical publications that could reveal us much more about the very works should become available. Considering that the Politika daily's content from 1904 to 1941 has been digitised as well as the feminophile ${ }^{6}$ journal Misao, ${ }^{7}$ along with the Serbian Literary Herald (1901-1941), the real challenge is actually contained in the digitisation of women's and feminist journals.

\section{Digitisation of women's and feminist magazines in Serbian}

\section{Project "Knjiženstvo" and research-based activism}

In this section, we will discuss certain aspects of the digitisation of women's and feminist magazines in Serbian. Feminist-oriented initiatives and projects within primarily research institutions (institutes, archives,

\footnotetext{
${ }^{6}$ Stanislava Barać's term (v. Barać, 2015).

${ }^{7}$ http://www.digitalna.nb.rs/Login.jsp?redirect=NBS/Novine_i_casopisi/Misao_ 1919-1937.
} 
libraries), educational institutions (universities), and women's/feminist non-governmental organisations prove to be the natural environment for such endeavours. The project Knjiženstvo ${ }^{8}$ represents such an environment for two reasons: 1) its subject - it is dedicated to women's culture and work (the project encompasses the research of fiction, essays, journals, memoirs, literary, theatre and other reviews, various artistic practises, such as dance, testimonies on the charity and pedagogical work of women's societies); 2) its structure - it consists of a digital database ${ }^{9}$ and electronic journal (a forum for the interpretation and theorisation of the materials from the base). ${ }^{10}$

The digital database Knjiženstvo should not be confused with a women's archive: this database offers information on authors and editors (biographical and bibliographical information), but does not offer - except in rare instances - the works themselves. ${ }^{11}$ Women's archives aim to document women's activities in the past, by preserving all available documents (digitised literary work, magazines, letters, memoirs, etc.). Such documents present both personal memories and historical evidence of women's activities in the past. However, despite the fact that it is not a women's archive, the project Knjiženstvo has similar goals as many women's archives initiated since the 1970s till today, so it is quite familiar with the idea of research-based activism: ${ }^{12}$

1. The basic goal of Knjiženstvo is to find forgotten and/or marginalised women writers that have not been included in the history of the

${ }^{8}$ It should be noted that all research projects funded by the Ministry of Education, Science and Technological Development ended in January 2020. In 2019, the Fund for Science (http://fondzanauku.gov.rs/?lang=en) was established, which takes over the organization of all calls, the evaluation process and the funding of research projects. In the transition period, until January 2021, the researchers on the project Knjiženstvo will have financial support. After that, the survival of Knjiženstvo (the database and the journal) will depend on the initiative and effort of researchers on the project.

${ }^{9} \mathrm{~V}$. http://knjizenstvo.etf.bg.ac.rs/sr.

${ }^{10} \mathrm{~V}$. http://www.knjizenstvo.rs/magazine.php.

${ }^{11}$ Even if Knjiženstvo decided to collect works themselves, it would focus on the already published works by women authors (either by offering digitized articles/books or by providing links to other websites where such materials have been stored).

${ }^{12}$ On this topic, v. i.e. classic pieces by Howard Zinn, (1977, 14-26), and Patrick M. Quinn, (1977, 25-35), as well as Vladan Vukliš and Anne J. Gilliand (2017, 186-199; 2016, 14-25 [in English]). 
Serbian culture and/or literature or curriculum of the Department of Serbian Literature.

2. The digital database Knjiženstvo represents an intervention of sorts in what is perceived as "official knowledge" (Apple, 1993); when the category of gender is placed at the centre of research, together with the women's experience (experience of an oppressed, subordinate group in society throughout history), the dominant histories simply become inaccurate (or, at best, incomplete). This is, therefore, an essential change of the knowledge base, and not mere "addition" of new/different knowledge to regular history.

3. Both the database and the journal Knjiženstvo enable interested students (mostly in master's and doctoral studies), and interested young researchers to find guidelines, that is, specific materials for dealing with women's works and to engage in writing a different history of culture and literature.

4. Since the database is online and available to everyone, it represents a step forward into the public space. The data stored there, as well as research papers written about the authors from the database and published in the electronic journal Knjiženstvo are visible to the wider public. This should be one of the fundamental goals of knowledge production: it should be available to the community in which it is made. In time, it should become relevant to that community.

\section{Criteria of selecting women's and feminist magazines for digitisation}

In the case of the project Knjiženstvo, there would be two criteria for selecting the magazines for digitisation: periodization (women editors born until 1915) $)^{13}$ and concept (the mission and the orientation of the magazine: what makes a magazine a women's, i.e. feminist magazine). But first, a theoretical and methodological remark on the phrase "women's magazines" should be considered. Slobodanka Peković correctly notes that

\footnotetext{
${ }^{13}$ In some cases, editors were men, but only nominally: men were legally enabled to establish and own the magazine, while in fact a group of women did all the editorial work.
} 
the determiner "women's" in the phrase women's magazines "is neither clear nor determined":

You cannot immediately discern whether those are magazines for a particular group or type of reader or whether those are, on the contrary, magazines created by a certain group or type. Are those magazines for women or are they edited, filled, illustrated by women? (Peković, 1990, 135).

In this text, we rely on the idea that the research of women's periodicals refers to the periodical press edited and shaped by women. Such magazines, especially at the turn of the $20^{\text {th }}$ century, represented a public space in which women could work and earn money, express certain stances and requests (educational, political, economic, etc.) and publish their literary texts.

The phrase "feminist magazines" is even more complex, especially when it comes to the end of the $19^{\text {th }}$ and the beginning of the $20^{\text {th }}$ century in this region, as well as in Europe and the USA. In an article about feminists and anti-feminists in Edwardian Britain, Lucy Delap $(2005,382)$ says that the term feminism doesn't have a stable meaning at the beginning of the $20^{\text {th }}$ century, when its use is becoming more widespread. In other words, there is no set of ideas, themes and methods that every feminist should know and apply at that time. That is why it was possible for many suffragettes not to be feminists and it is also why many feminists criticised the narrow frameworks of the fight for women's suffrage (Kolarić, 2016; 2017). When it comes to the local context, it is sufficient to recall the tight bond between the demands of women for education, the right to work and, later, the right to vote on the one hand and the support to the national idea and interests reflected in accepting traditional, patriarchal patterns of behaviour on the other in the magazine Žena (Woman) edited by Milica Tomić. This means that, before the digitisation of magazines, it is necessary to consider and define terms and categories, while taking into consideration their limitations and inevitable reductive nature.

The only possible way to overcome numerous traps of categorisation and classification ${ }^{14}$ would be non-normative inclusivity in digitisation. In

${ }^{14}$ The notion of feminism is inherently a notion of values. In other words, if we are guided by feminist principles in magazine, digitisation from today's perspective, it is likely that we will neglect some magazines, or texts of women/on women in certain magazines. 
their book, Modernism in Magazines, Robert Scholes and Clifford Wulfman $(2010,44)$ propose an important methodological turn in the study of modern periodicals that digital archives have enabled: a turn from genres to databases. According to them, we must make "a move from ideological or cultural constructions to the collection of data," and those data will make the magazines "searchable" in regard to various research inquiries (Scholes, Wulfman, 2010, 44). In other words, Scholes and Wulfman advocate more descriptive (non-normative) magazine categories. They also explain that request by pointing to the problematic nature of certain categories and genres used to describe magazines, such as "little magazines" and "literary" magazines. Also, we should take into consideration the conclusion of Slobodanka Peković that the phrase "women's magazine" is still more comprehensive than the phrase "feminist magazine":

I am still wary of the notion feminism. I think this notion would narrow the field of research. Feminism is an important movement at the beginning of the twentieth century; it is also significant today because, regardless of all political and legal proclamations, the stereotypes of the place, abilities and possibilities of women are still present. "The feminist approach in periodical studies" or "feminist periodical studies" are unavoidable terms when working on women's periodicals. However, we should not limit ourselves solely to that form of research. Where, then, would we place those magazines which are protofeminist, feminophile, or merely intended for women? All magazines which have enabled women to express themselves, which encouraged or approved of their activities and achievements, are equally important. Even those which are on the opposite side, extremely against feminism, against women's engagement outside of the household - are relevant, because they represent the other, dark side of a mirror which reflects the degree of human - women's rights, i.e. minority rights (Peković, 2016).

Simply, the criteria for selecting magazines that will be digitised will be the subject of a complex theoretical and methodological - as well as socially and politically significant - discussion.

\footnotetext{
Tanya Zanish-Belcher and Kären M. Mason $(2007,348)$ write about a similar problem in the case of women's archives formed under the strong influence of feminist activism and theory: "[...] women's archives today may have a feminist bias and may fail to document groups that do not share these values or who actively oppose these values, such as right-wing organizations or right-to-life groups. Archivists must therefore be conscious of and open about their biases, carefully evaluating the decisions they make about collection development."
} 


\section{Reasons for the digitisation of women's and feminist magazines}

The first evident reason for the digitisation of women's and feminist magazines is the preservation of cultural heritage in the broadest sense. The state of most of these magazines is concerning: in many cases, the paper is damaged, and there are not many copies (and there are not many libraries that have all volumes of a magazine). The theoretically, historically and socially significant reason for the digitisation of the magazines stems from their negligible visibility and availability: an important part of the domestic social, cultural and literary history has been marginalised, and often excluded from what is typically called "official knowledge." It is likely that students of Serbian or comparative literature, regardless of the preferences of their professors, will encounter magazines such as The Egoist or Misao (Thought) while preparing exams or reading secondary literature. However, we can safely assume that students will hear about The Freewoman, ${ }^{15}$ Žena (Woman) ${ }^{16}$ or Žena danas (Woman Today) only if professors decide to talk about them. Namely, while the former magazines are part of the cannon mediated by the curriculum, the latter are dependent on the selection and preferences of the professors. Also, we need to recall here the famous text by Raymond Williams, "The Analysis of Culture" (1961), in which he writes that the (cultural) tradition of a society is the result of the process of incessant selection and interpretation, that is, the selection and re-selection of our ancestors, mostly from the perspective of the present which is shaped by certain interests and values (gender, ethnic/racial, class...). Williams believes that the education system must have a key role in overcoming the selectiveness and reductionism inherent in the notion of tradition:

Within a given society, selection will be governed by many kinds of special interests, including class interests. [...] In theory, and to a limited extent in practice, those institutions which are formally concerned with keeping the tradition alive (in particular the institutions of education and scholarship) are committed to the tradition as a whole, and not to some selection from it according to contemporary interests. [...] [A] wise society $[\ldots]$ will encourage the institutions to give sufficient resources to the ordinary work of preservation, and to resist the criticism, which any particular period may make

\footnotetext{
${ }^{15} \mathrm{~V}$. https://modjourn.org/journal/freewoman/.

${ }^{16} \mathrm{~V}$. http://knjizenstvo.etf.bg.ac.rs/sr/serial-publications/zena.
} 
with great confidence, that much of this activity is irrelevant and useless (Williams, 1998, 55).

If we connect these still relevant guidelines by Raymond Williams to the domestic context and the subject of this text, we can conclude that there are at least two reasons for the institutionally supported digitisation of women's and feminist magazines:

1. The task of educational and academic institutions, that is, lecturers and researchers in the field of humanities and social sciences, is to mediate cultural tradition in the broadest sense, and to collect and discuss past and present findings about it.

2. The digitisation of these magazines would open space for new areas of research and the finding of new knowledge, which would make humanities vibrant and relevant. That is especially important at a moment in which the education policy in Serbia - recklessly and thoughtlessly - is being tailored exclusively towards the needs of the economy, that is, the labour market, for the purpose of achieving profit. ${ }^{17}$

As it was mentioned earlier, the digitisation of women's and feminist magazines would enable researchers of periodicals to work on less researched and readily available material, as well as new, often comparative topics. However, a more important consequence of digitisation and analysis of those magazines would be a different understanding of history of (literary) periodicals and history of literature, as well as cultural history in principle. Let us recall the question that Rita Felski asks in the study The Gender of Modernity, when she analyses the complex relation between modernity and numerous representations of womanhood by reading certain texts from the age of modernity (literary texts, newspaper articles, essays) from the perspective of feminist theory:

How would our understanding of modernity change if instead of taking male experience as paradigmatic, we were to look instead at texts written primarily by or about women? And what if feminine phenomena, often seen as having a secondary or marginal status, were given a central importance in the analysis of the culture of modernity? What difference would such a procedure make? (Felski,1995, 10).

${ }^{17}$ Such an educational policy results in numerous poor practices and initiatives. It is sufficient to name one here - dual education (v. Reljanović; Ilić, 2017; Jovanović; and on the public discussion on the draft of the Law on Higher Education v. Janković). 
Felski stresses that we - researchers and interpreters - are constructing the past from the perspective of the present, which is why we must constantly bear in mind the complex relationship between past and present value systems and world views so we avoid simplified interpretations - or partially unjust disputes - of texts from the past (Felski, 1995, 33-34). While considering comparative history of literature, Mario Valdés and Linda Hutcheon also warn of the aspect of "dialectic of past and present" in the interpretation of historians which consider (literary) texts of the past to be simultaneously testimonies of the past and experiences of the present (Valdés, Hutcheon, 1994, 6; 2002). In an attempt to re-examine and reconceptualise the traditional model of the history of literature, Valdés and Hutcheon rely on the conclusion of Hayden White that meaning of historical research is not found in merely recording the facts and events, but also in the need to interpret what certain events mean to a certain group of people, society or culture (according to Valdés, Hutcheon, 1994, 6). According to these authors, the history of literature actually represents a complex history of production and reception of texts (texts that are not exclusively "literary"), which can be understood by taking into consideration the economic, political, social and other contexts, as well as categories of gender, class, race.

How are these stances connected to the digitisation of women's and feminist periodicals in Serbian? It is indisputable that studying these magazines represents an intervention into the dominant understanding of domestic literature and cultural history. ${ }^{18}$ However, such an intervention should lead to thorough theoretical and curriculum changes, not simply to "adding women" in side notes and footnotes. Simply, this is not just about mere modification or correction of existing history, but rethinking the existing postulates in writing history (of literature) and their essential reshaping. ${ }^{19}$

${ }^{18} \mathrm{~V}$. for instance, texts and books on women's, feminist and feminophile magazines by Slobodanka Peković, Stanislava Barać, Jelena Milinković, Ana Kolarić, Žarka Svirčev and other authors.

${ }^{19}$ In principle, the history of periodicals, including women's and feminist periodicals, brings some of the basic postulates of the history of national literature into question. In 1984, the publication consisting of catalogued literary periodicals issued between 1768 and 1941 was published, as well as several articles written by the editors of the catalogue. In the 


\section{Good practices}

The Modernist Journals Project (http://www.modjourn.org/) ${ }^{20}$ represents an example of the successful digitisation of magazines and the creation of a digital scientific and research environment. The project was initiated at Brown University in 1995, and since 2003, the University of Tulsa has participated in its implementation. ${ }^{21}$ The project was envisioned and led between 1995 and 2012 by Robert Scholes. The leaders of the project on modernist magazines, much like its advisors and researchers, mostly come from the fields of literary studies (and are particularly interested in modernity and modernism), periodical studies and media studies, as well as digital humanities. This project encompasses magazines issued in English from 1890 to 1922, regardless of their geographical location. The end year is conditioned in two ways: intellectually (this year is considered the pinnacle of modernist literature that was marked by the publishing of Joyce's Ulysses, T.S. Eliot's Wasteland and Virginia Woolf's Jacob's Room) and practically (as of 1923, the situation regarding copyright becomes increasingly complicated). In the history of the project, it is stressed that the focus during the first years was exclusively on the digitisation of magazines and added materials. It is only later that tools for the use of those materials were developed, such as the section "Teaching \& Research." 22 The significance of the project can be summarised in the slogan that "modernism began in magazines." 23

introduction, signed by Dragiša Vitošević, Đorđije Vuković and Aleksandar Petrov, it is said that "strict national demarcation of periodicals, much like national literature, cannot be done completely." That is why, while writing histories of national literatures and the histories of periodicals, "principles of dual or even tripartite affiliation, corresponding to the nature of those things, have to be honoured" (Vitošević, Vuković et al., 1984, 7). That is why it is not surprising that the catalogue of magazines the authors created included the magazines that can be designated simultaneously as Serbian, Croatian or even Yugoslav. Aside from concluding that the category of national is relative and mutable, authors rightfully claim that our perception of what is "literary," that is, what a "magazine" is, is subject to frequent changes considering that both notions keep being redefined with time.

${ }^{20}$ Hereinafter: MJP.

${ }^{21}$ All data were taken from the website https://modjourn.org/about/.

${ }^{22} \mathrm{~V}$. https://modjourn.org/teaching-and-research/.

${ }^{23}$ The turn of phrase "modernism began in magazines" serves as the slogan of the MJP project, and Scholes and Wulfman provide the arguments for that in the book Modernism in Magazines (2010). 
The digitisation of women's and feminist magazines in Serbian should be based on the MJP. Within the project "Ženski pokret 2020" (Women's Movement 2020) at the end of 2019, the digitisation of the magazine Ženski pokret (1920-1938) was finalised and the bibliography of the magazine was published (Poljak and Ivanova, 2019). ${ }^{24}$ According to the basic idea, the project is reminiscent of the digital archive of the MJP. It is imagined as a project in the field of digital humanities. It has a website that includes digitised issues of the magazine, a bibliography of the magazine in PDF (considering that the bibliography was first published as a print edition), existing secondary sources on the magazine, information about the international research conference that will be held in the autumn 2020, entirely dedicated to the magazine, as well as sections "Gallery" and "News" which keep track of events regarding the project/magazine. Much like the digital archive of modernist magazines, "Women's Movement 2020" offers a digital scientific and research environment. In that sense, this project can serve as a role-model for the digitisation of other women's and feminist magazines in Serbian.

Aside from the aforementioned elements (digitised magazine, bibliographic data, list of research papers and books by domestic and foreign authors dealing with the analysis of the magazine), the specific contribution of the project Knjiženstvo, should it choose to delve into the digitisation of women's and feminist magazines, would reflect in creating a "digital classroom", which would consist of materials and tools for teaching and researching periodicals, as well as room for publishing discussions and research made during the implementation of the subject from the studies of women's and feminist periodicals, mostly in postgraduate studies. ${ }^{25}$

${ }^{24}$ The project was created and initiated by Jelena Milinković and Žarka Svirčev within the activities of the Institute for Literature and Arts in Belgrade. V. https://www.zenskipokret. org/.

${ }^{25}$ Three courses on women's and feminist periodicals are currently being taught at the Faculty of Philology, University of Belgrade, within masters and doctoral studies: "Žanr i rod" (Genre and Gender), "Ženska/feministička i feminofilna štampa između 1890. i 1941. godine" (Women's/Feminist and Feminophile Press in Serbia/Yugoslavia Between 1890-1945), "Teorija, aktivizam i kulturne/umetničke prakse: feministička štampa u Srbiji 90-ih i 2000-ih godina" (Bringing Theory, Activism and Cultural Practices Together: Feminist Press in Serbia in the $90 \mathrm{~s}$ and $2000 \mathrm{~s}$ ). 


\section{Conclusion}

The digitisation of women's and feminist magazines and the creation of the aforementioned platform, that is, linking the existing platforms, would offer information about existing research of women's and feminist periodicals, both in Serbia and elsewhere. It would also instigate new research and the creation of new knowledge. The platform would enable a relatively simple connection of researchers working in similar areas and it would contribute to the wider availability and visibility of research papers, as well as the democratisation of knowledge. ${ }^{26}$ Understandably, the presence of such a platform in public would require dedicated and patient work, and the principled belief of most researchers that knowledge should and must be relevant for the political, that is, social community.

The most important consequence of the digitisation of women's and feminist magazines would reflect in the essential intervention into the history of literature and culture. In that sense, the digitisation of these magazines, and the work on them, would point to a fact that education institutions do not stress sufficiently: changes in society depend on numerous factors, including the activities of individual actors or groups. In the case of women's and feminist periodicals, these include women who dedicated their lives to the fight for equal political, economic, educational rights and who showed that a different world was possible. It is our duty, in research papers and the classroom, to preserve the memory of the numerous and difficult struggles those women led, and the results of those fights.

Translated by Višnja Krstić and Radojka Jevtić

\section{References}

Apple, M. (1993). Official Knowledge: Democratic Education in a Conservative Age. New York: Routledge.

\footnotetext{
${ }^{26}$ Visibility, availability and democratization of knowledge are basic tenets advocated by the proponents of digital humanities. "For the digital humanities, information is not a commodity to be controlled but a social good to be shared and reused" (Spiro, 2012, 21). It seems as though these values should be fundamental for humanities in general.
} 
Burdick, A., Drucker, J., Lunenfeld, P., Presner, T., Schnapp, J. (2012). Digital Humanities. Cambridge-London: The MIT Press.

Delap, L. (2005). Feminist and anti-feminist encounters in Edwardian Britain. "Historical Research" vol. 78, no. 201, pp. 377-399. https://doi.org/10.1111/j.1468$-2281.2005 .00235 . x$.

Dimitrijević, J. J. (1986). Pisma iz Niša (o haremima). Ur. S. Peković. Beograd: Narodna biblioteka Srbije.

Dimitrijević, J. J. (2003). Đul Marikina prikažnja. In: Pisma iz Niša (o haremima) / Đul Marikina prikažnja. Ur. J. Jovanović. Niš: Prosveta, pp. 141-191.

Dimitrijević, J. J. (2008). Pisma iz Soluna [bilingual edition]. Prev. D. Stratigopulos, V. Bošković. Loznica: Karpos.

Dimitrijević, J. J. (2012). Nove. Sopstvena soba. Beograd: Službeni glasnik.

Dimitrijević, J. J. (2016a). Đul Marikina prikažnja, „Priča, časopis za priču i priče o pričama; književno društvo 'Sveti Sava”" vol. X, br. 36, pp. 140-193.

Dimitrijević, J. J. (2016b). Sedam mora i tri okeana, putem oko sveta. Beograd: Laguna. Dimitrijević, J. J. (2017). Pisma iz Indije. Ur. A. Stjelja. Prev. Ž. V. Mitić (engleski), L. Chawda (hindi). Beograd: Ana Stjelja.

Dimitrijević, J. J. (2019). Novi svet ili U Americi godinu dana. Beograd: Laguna.

Dimitriyévitch, Y. Y. (2020). Au soleil couchant, [bilingual edition]. Beograd: Filološki fakultet Univerziteta u Beogradu - Narodna biblioteka Srbije.

Felski, R. (1995). The Gender of Modernity. Cambridge: Harvard University Press.

http://knjizenstvo.etf.bg.ac.rs. 13.10.2020.

http://www.knjizenstvo.rs. 13.10.2020.

https://modjourn.org. 13.10.2020.

https://www.zenskipokret.org/. 13.10.2020.

Hutcheon, L., Valdés, M. J. (eds.) (2002). Rethinking Literary History. A Dialogue on theory. Oxford: Oxford University Press.

Ilić, D. (2017). Izrabljivanje dece. Peŝčanik. http://pescanik.net/izrabljivanje-dece/. 13.10.2020.

Janković, M. (2017). Jedna rasprava. Peščanik. http://pescanik.net/jadna-rasprava/. 13.10.2020.

Jovanović, A. (2017). Kako od dece napraviti ljude. Peščanik. http://pescanik.net/kako-od-dece-napraviti-ljude/. 13.10.2020.

Knjiženstveni Beograd (GynoCentric Belgrade) interactive map. https://www.google. $\mathrm{com} / \mathrm{maps} / \mathrm{d} / \mathrm{viewer}$ ?mid=1xdIQP60-03MJbAm7KTBGY7n-JDA\&1l=44.8149329 $028337 \% 2 C 20.458130849999968 \& z=16.13 .10 .2020$.

Kolarić, A. (2017). Rod, modernost i emancipacija. Uredničke politike u časopisima Žena (1911-1914) $i$ The Freewoman (1911-1912). Beograd: Fabrika knjiga.

Mitrović, Đ. (2017). Na putu ka blagostanju 4.0 - Digitalizacija u Srbiji. Beograd: Friedriech Ebert Stiftung.

Quinn, P. M. (1977). The Archivist as Activist. "Georgia Archive" 5/1, pp. 25-35.

Reljanović, M. (2017). Da li ćemo im i decu oprostiti. Peščanik. http://pescanik.net/ da-li-cemo-im-i-decu-oprostiti/. 13.10.2020. 
Scholes, R., Wulfman, C. (2010). Modernism in the Magazines. An Introduction. New Haven-London: Yale University Press.

Spiro, L. (2012). 'This Is Why We Fight': Defining the Values of the Digital Humanities. In: Debates In the Digital Humanities. Eds. M. K. Gold. Minneapolis: University of Minnesota Press, pp. 16-35. https://doi.org/10.5749/minnesota/9780816677948. 003.0003 .

Valdés, M. J., Hutcheon, L. (1994). Rethinking Literary History - Comparatively. "American Council of Learned Societies Occasional Paper" no. 27, pp. 1-13.

Vukliš, V., Gilliand, A. J. (2016). Archival Activism: Emerging Forms, Local Applications, In: Archives in the Service of People-People in the Service of Archives. Ed. B. Filej. Maribor: Alma Mater Europea, pp. 14-25.

Vukliš, V., Gilliand, A. J. (2017). Arhivski aktivizam: nove forme i lokalne primjene. „Glasnik arhiva i Arhivističkog udruženja Bosne i Hercegovine” 47, pp. 186-199.

Williams, R. (1998). The Analysis of Culture. In: Cultural Theory and Popular Culture. A Reader. Ed. J. Storey. Athens: University of Georgia Press, pp. 48-56.

Williams, R. (2006). Analiza kulture. Prev. V. Kirinić. In: Politika teorije. Zbornik rasprava iz kulturalnih studija. Prir. D. Duda. Zagreb: Disput, pp. 35-58.

Zanish-Belcher, T., Mason, K. M. (2007). Raising the Archival Consciousness: How Women's Archives Challenge Traditional Approaches to Collecting and Use, or, What's in the Name? "Library Trends" 56, pp. 344-359. https://doi.org/10.1353/ lib.2008.0003.

Zinn, H. (1977). The Secrecy, Archives, and the Public Interest. "The Midwestern Archivist" 2/2, pp. 14-26.

Бараћ, С. (2015). Феминистичка контрајавност: жанр женског портрета y српској периодици 1920-1941. Београд: Институт за књижевност и уметност.

Витошевић, Д., Вуковић, Ђ. et al. (1984). Српска кюижевна периодика 1768-1941. Београд: Институт за књижевност и уметност.

Дојчиновић Б., Коларић, А. (2017). Ка другачијем знању: база података Књиженство и дигитализација материјала. "Књижевна историја, часопис за науку о књижевности” XLIX, 163, pp. 195-211. http://knjizevnaistorija.rs/ editions/163/10_Dojcinovic.pdf. 13.10.2020.

Дојчиновић, Б. (2016). Историја дисииплине која то није: од појма рода до дигиталне хуманистике. In: Компаративна кьижевност: теорија, тумачења, перспективе. Прир. А. Марчетић, 3. Бечановић Николић, В. Елез. Београд: Филолошки факултет Универзитета у Београду, pp. 75-84.

Дојчиновић, Б. (ур.) (2019). Американке Јелене Ј. Димитријевић. Зборник радова. Београд: Филолошки факултет Универзитета у Београду - Народна библиотека Србије. https://doi.org/10.18485/jd_amerikanke.2019.

Коларић, А. (2016). Дора Марсден и The Freewoman: уређивачка политика и идејни плурализам. "Књиженство” бр. 6. http://www.knjizenstvo.rs/magazine.php? text=199. 13.10.2020. https://doi.org/10.18485/knjiz.2016.1.9. 
Кох, М. (2017). Extra muros у канону: Јелена Димитријевић у настави српске књижевности на универзитетима у Пољској. In: Читате ли Јелену Димитријевић? Ур. Б. Дојчиновић, Ј. Милинковић. Београд: Филолошки факултет Универзитета у Београду, pp. 1-21. https://doi.org/10.18485/jdimitrijevic.2018.ch2.

Пековић, С. (1990). Женски часописи с почетка века. Прилози за историју српске књижевне периодике. Ур. А. Петров. Београд-Нови Сад: Институт за књижевност и уметност Матице српске.

Пековић, С. (2016). Прошло је време нечујности / The Time of Silence Has Passed (interview conducted by Ana Kolarić and Stanislava Barać). "Књиженство” бр. 6. http://www.knjizenstvo.rs/magazine.php?text=176. 13.10.2020.

Пољак, Ј., Иванова, А. (2019). Женски покрет (1920-1938): библиографија. Београд: Институт за књижевност и уметност.

[Barać, S. (2015). Feministička kontrajavnost: žanr ženskog portreta u srpskoj periodici 1920-1941. Beograd: Institut za književnost i umetnost.

Vitošević, D., Vuković, Đ. et al. (1984). Srpska književna periodika 1768-1941. Beograd: Institut za književnost i umetnost.

Dojčinović, B., Kolarić, A. (2017). Ka drugačijem znanju baza podataka Knjiženstvo i digitalizacija materijala. "Književna istorija, časopis za nauku o književnosti" XLIX, 163, pp. 195-211. http://knjizevnaistorija.rs/editions/163/10_Dojcinovic. pdf.

Dojčinović, B., (2016). Istorija discipline koja to nije: od pojma poda do digitalne xumanistike. In: Komparativna književnost: teorija, tumačenjam perspektive. Prir. A. Marčetić, Z. Bečanović Nikolić, V. Elez. Beograd: Filološki fakultet Univerziteta u Beogradu, pp. 75-84.

Dojčinović, B., (ur.) (2019). Amerikanke Jelene J. Dimitrijević. Zbornik radowa. Beograd: Filološki fakultet Univerziteta u Beogradu - Narodna biblioteka Srbije.

Kolarić, A. (2016). Dora Marsden $i$ The Freewoman: uređivačka i idejni plurizam. "Knjiženstvo" br. 6. http://www.knjizenstvo.rs/magazine.php?text=199.

Koh (Koch), M. (2017). Extra muros $u$ kanonu:JelenaDimitrijević u nastavi srpske književnosti na univerzitetima u Poljskoj. In: Čitate li Jelenu Dimidtrijecić? Ur. B. Dojčinović, J. Milinković. Beograd: Filološki fakultet Univerziteta u Beogradu, pp. 1-21.

Peković, S. (1990). Ženski časopisi s početka veka. Prilozi za istoriju srpske književne periodike. Ur. A. Petrov. Beograd-Novi Sad: Institut za književnost i umetnost Matice srpske.

Peković, S. (2016). Prošlo je vreme nečujnosti / The Time of Silence Has Passed (interview conducted by Ana Kolarić and Stanislava Barać). "Knjiženstvo", br. 6. http:// www.knjizenstvo.rs/magazine.php?text=176.

Poljak, J., Ivanova, A. (2019). Ženski pokret (1920-1938): bibliografija. Beograd: Institut za književnost i umetnost]. 